\title{
THE CONSTITUTIONAL HURDLES TO EXERCISE SECESSION RIGHT AND ARGUMENTS ON ITS INCLUSION IN THE ETHIOPIAN CONSTITUTION
}

\author{
Teshale Shambel* \\ School of Law, Jinka University, Ethiopia, E-mail: teshaleshamb@gmail.com
}

(Received: September 2020; Accepted: October 2020; Published: November 2020)

\begin{abstract}
The right to self-determination is one of the human rights enshrined under the Ethiopian constitution. It is also one of the rights mentioned under ICCPR and ICESCR as well as the constitutions of different countries. Being unique to many other human rights instruments and constitutions in the world, the Ethiopian constitution includes the unconditional right to secession as a part of self-determination for every one of the ethnic groups (nations, nationalities, and people) in the country. As argued among many scholars, the inclusion of unconditional secession as a part of self-determination right in the Ethiopian constitution was based on the wrong narrative that nations, nationalities and people in the country were oppressed. Thus, it is a point of political debate between elites and became the major cause of widening the divergence among views of different political parties in the country. Of course, within the constitution, there are hurdles that can potentially deny exercising of this right. Therefore, this study qualitatively analyses the impracticability of secession and unacceptability of narratives to its inclusion in the constitution of the federal democratic republic of Ethiopia.
\end{abstract}

Keywords: secession, self-determination, constitution, Arguments, hurdles.

\section{Introduction}

Ethiopia is one of the multi-ethnic polities in Africa. It has passed through different regimes in the last few centuries. Under the guise of democratization to satisfy different interests of groups and people in the country, the country has changed its constitution four times within a single century. The 1995 constitution is the last and the current working constitution that established an ethnic-based federal state structure in which all ethnic groups (nations, nationalities, and people) have the unconditional right to self-determination including secession.

\footnotetext{
*Corresponding author: Teshale Shambel. E-mail: teshaleshamb@gmail.com.
} 
Shambel, T., (2020)

The constitutional hurdles to exercise secession right and arguments on its inclusion in the Ethiopian Constitution

The major justification that has been repeatedly raised by the framers of the constitution for the inclusion of a secession clause in the constitution was their view that there was 'nation oppression' during former regimes (Merara 2003). They believe that one of the ethnic groups, (Amhara) has oppressed other ethnic groups so that including a secession clause in the constitution guarantees other ethnic groups that the state is not going back to ethnic oppression in the future (Abate, 2004). This idea drew much attention over ethnic groups in the country and debated among scholars and politicians. The main reason for those scholars who argue against the inclusion of a secession clause in the constitution was that they regarded it as based on a false narrative and it is a threat to the sovereignty of the state affecting the territorial integrity of the country.

In the recent past, ethnic-based liberation fronts like ONLF (Ogaden National Liberation Front) and OLF (Oromo Liberation Front) engaged in armed struggles and had been claiming independence of their respective ethnic groups by habitually pointing to this clause in the constitution. Of course, for now, both of the abovementioned liberation fronts left their old views aside and assimilated peaceful strugglers for democratization. Currently, another liberation front, the former member of a ruling coalition, TPLF (Tigrian Peoples Liberation Front) threatens the federal government to use this clause in the constitution to declare the independence of the people of Tigray if the federal government fail to reinstitute TPLF to its former hegemonic power position.

Of course, the procedures laid down in the constitution to exercise secession are very stringent so that it is practically not easy for an ethnic group to secede. Therefore, the main objective of this paper is to critically examine the arguments for inclusion of the secession clause and constitutional constraints that can potentially obstruct exercising of the right to secession under the FDRE constitution.

\section{Meaning and Scope of Application of Right to Self-determination}

People's right to self-determination is one of the fundamental rights included in international human rights covenants (covenant on civil and political rights and covenant on economic social and cultural rights). Even the UN Charter itself has also recognized the self-determination right of peoples as one of the purposes of the organization as it is stated under article 1 sub-article 3 of the charter. The idea of a right to self-determination of peoples originally emerged from socialist economic thought. Lenin (1870-1924) and Joseph Stalin (1879-1953) invented the concept in the early parts of the twentieth century to explain the standing of political communities within the over-arching and universal economic structures of communism (van der Vyver 2004). It became one of the concerns of the international human rights system particularly during the decolonization of people

38 sciendo Journal of Legal Studies Volume 26 Issue 40/2020 ISSN 2457-9017; Online ISSN 2392-7054.

Web: publicatii.uvvg.ro/index.php/jls. Pages $37-47$ 
Shambel, T., (2020)

The constitutional hurdles to exercise secession right and arguments on its inclusion in the Ethiopian Constitution

from their foreign aggressors (G. Pentassuglia 2002). Therefore, the major purpose of including self-determination in the international human rights system was to safeguard people from colonialism so that it is a means of decolonization and protection from foreign domination.

The right to self-determination has both internal and external dimensions (Antonio Cassese 1995). The internal dimension refers to people's right to internally administer themselves, to choose one's own government, the right of a group to be free from another's rule and to choose the sovereign and the right to democratic government. The external dimension is concerned about the international status of a people or it embraces secession and independence (Hernard 1999).

There is a difference in the understanding concerning the applicability of the external dimension of self-determination. The differences of view relate to extending the applicability of the external dimension of self-determination to substate groups like minorities. Those who argue for minorities and other sub-state groups to enjoy the external dimension of self-determination refer to the nonexistence of a clear prohibition in international law (Douglas Sanders 1986). But self-determination (external dimension) is not a right of sub-state groups, rather it is the right given to the whole people in the boundary of state so that it protects people of a given state from external domination (M. Suksi, 2005). This idea is clearly expressed in different UN General Assembly resolutions and advisory opinions of the international court of justice. The advisory opinions of the International Court of Justice on Namibia in 1971 and Western Sahara in 1975 are the best examples hereof (T, Kempin Reuter, 2016). Similarly, the UN Human Rights Committee, in the case between Apriana Mahuika et al. and New Zealand which decided that the right to self-determination (the external dimension) cannot be applied to the minorities because the right is only given to the people of the state in its entirety (T. Kempin Reuter, 2016). But there are a few exceptions for minorities and sub-state groups to exercise external self-determination, namely, if the group constitutes the "whole people" as discussed above, if the group is under colonial rule or subjected to gross human rights violations, or if the state voluntarily splits (T. Kempin Reuter 2016). When we see the practice of states today, no country in the world constitutionally recognizes external selfdetermination right for sub-state groups except Ethiopia.

\section{Arguments against and Narratives to Inclusion of Secession Right in the Ethiopian Constitution}

The 1995 constitution of Ethiopia is the only constitution in the world that clearly allows the disintegration of the country by including a secession clause if the ethnic groups (nations, nationalities and people) in the country want it. In this regard Article 39 sub-article 1 of the Ethiopian constitution states the following: 
Shambel, T., (2020)

Every Nation, Nationality and People in Ethiopia has an unconditional right to self-determination, including the right to secession.

The inclusion of the secession clause in the constitution has its own historic narratives. The narratives are related to the process of nation-building in the country. Concerning Ethiopian nation-building, there are different views of different scholars. The argument that is mentioned in different works of literature was that Ethiopia was founded on excessive and forceful centralization that ignored the ethnolinguistic diversities so that ethnic groups in the country need freedom. This view is held by a majority of liberation fronts and political parties that were formed to promote freedom of particular ethnic groups. They blame that all the regimes before the current constitution were unwelcomed centralizers who caused ethnic tension in the country. The framers of the current constitution were those former liberation fronts which later formed the Ethiopian People's Revolutionary Democratic Front (EPRDF), which later on totally dominated by TPLF (Tigray Peoples Liberation Front). All of the liberation fronts were the products of the Ethiopian Student Movement of the 1960s that focused on the "oppression of nationalities," that is, ruling elites of former regimes were mostly from one nationality controlling power, resources and narrowly defining the values and institutions of the state (Abate 2004). Sometimes, a few political elites even went further to state that the former regimes must be seen as a form of "internal colonialism" in which Amhara colonized other ethnic groups in the country. Based on this narrative, the current constitution of Ethiopia clearly states that there was an unjust relation between ethnic groups (FDRE constitution 1995). It was this narrative that guided the formulation of an ethnic-based federal system in which ethnic groups (nations, nationalities, and people) have an unconditional right to self-determination and secession. Thus, for them, the inclusion of the secession clause under the constitution is justified because historically ethnic groups were oppressed or colonized by one ethnic group; therefore, secession is a constitutional guarantee for the ethnic groups that the country is not going back to the original unjust relation in which one ethnic group oppressed others. Furthermore, they believed that all ethnic groups were independent states and forcefully assimilated to Ethiopia but willfully formed current Ethiopia under the guidance of this constitution so that if they want to secede from the country, they can do unconditionally. But there is no tangibly proved evidence which shows the ethnic groups (the nations, nationalities, and people) in the country were independent state forcefully assimilated to Ethiopia. No one of them had their own independent and internationally recognized state. Neither of them fulfills those exceptional conditions in which sub-state groups can exercise the external self-determination right as discussed in part two of this paper. But the constitution granted them the right to secession unconditionally. 
Shambel, T., (2020)

Some scholars consider that forceful centralization by former regimes was all a normal process of "nation building" which was not different from the nationbuilding history of other countries in the world and hence consider the liberation struggles as a form of tribalism (Jon Abbink ${ }^{1998)}$. Followers of this view say that 'nation oppression thesis' is a false narrative constructed by TPLF, the mastermind in framing the current constitution of the country. They blame TPLF for its hidden agenda of seceding Tigray by falsely accusing Amharas as an oppressor (Belete 2018). In their view, there was no dominant ethnic group which oppressed others in the country. They further state that in the former regimes there was class oppression rather than nation oppression where the ruling class oppressed all ethnic groups in the country (Merara 2003). For them, there was no beneficiary single ethnic group rather all of the ethnic groups were the victims of the former systems but one ethnic group (Amhara) is falsely accused as the enemy of other ethnic groups though it struggled to overthrow the former regimes together with other ethnic groups for the democratization of the country. Therefore, the current constitution is a threat to the sustainability of the country because it allows the disintegration of the country by including a secession right which is based on false narratives of national oppression as discussed above (Clapham, 2002). Currently, this view got support from the mass population particularly after TPLF (the former member of the ruling coalition) started claiming the secession of the people of Tigray. But it is not easy to secede because the constitution itself has included hurdles that can make secession impossible.

\section{Procedural Hurdles to Exercise Secession Right in Ethiopia}

As discussed above, though there is no national consensus on the inclusion of secession in the Ethiopian constitution, all the ethnic groups (nations, nationalities and people) in the country have an unconditional right to self-determination including secession. The right is given unconditionally means that if an ethnic group wants to secede, it can be granted without producing any justification for this to happen, provided that it passes through procedures stated in the constitution. Article 39 sub-article 4 of the constitution lays down the following procedures to exercise secession:

The right to self-determination, including secession, of every Nation,

Nationality and People shall come into effect:

(a) When a demand for secession has been approved by a two-thirds majority of the members of the Legislative Council of the Nation, Nationality or People concerned;

(b) When the Federal Government has organized a referendum which must take place within three years from the time it received the concerned council's decision for secession; 
Shambel, T., (2020)

(c) When the demand for secession is supported by majority vote in the referendum; (d) When the Federal Government will have transferred its powers to the council of the Nation, Nationality or People who has voted to secede; and

(e) When the division of assets is effected in a manner prescribed by law.

As we can see from this article of the constitution, though the right is given to nations, nationalities and peoples unconditionally, the procedures to be observed before declaring secession are not easy. The first of the five procedural steps are getting two-thirds majority approval from the members of the legislative council of the concerned nation, nationality, and people. This means around 75 percent of the members of the council must vote for it. This step can be taken as easily only if the seats in the legislative council are occupied by a single party or parties with similar views, as it is now, but it might be hard to get two-thirds majority approval in cases when competitive political parties are holding little more than a one-third majority in the legislative council of the Nation, Nationality or People concerned. Thus, if the secession question is supported by the members below a two-thirds majority in the legislative council of concerned Nation, Nationality or People, it will fail there in its first place.

The second step which comes next to the first step is the organization of a referendum by the federal government which must take place within three years from the time the federal government received the concerned council's decision for secession. The main problem with this procedure is what will happen if the federal government does not organize the referendum for different political reasons. The constitution is silent with regard to what measures are to be taken if the federal government is not willing to organize a referendum. It is obvious that the federal government and its institutions, like the house of the federation which is composed of persons from different nations, nationalities and people; and representing different interests may never approve to hold a referendum. Therefore, it is another hurdle to cross before declaring secession.

The third step is when the demand for secession is supported by a majority vote in the referendum that is organized by the federal government. This is comparatively easier than the first and the second procedural steps. An unanswered question concerning this procedural step is that the constitution does not show who can or cannot vote in the referendum. The question here is whether all citizens residing in the area questing for secession can cast their vote or are the only members of the concerned ethnic group the only persons who have the right to vote. Citizens freely reside in different parts of the country and invest confidently in their territories, therefore, denying them and allowing only members of the concerned ethnic group to vote is unfair. But if the non-members of the concerned ethnic group vote in the referendum, it may hamper getting a majority vote, particularly in the areas where

42 Sciendo Journal of Legal Studies Volume 26 Issue 40/2020 ISSN 2457-9017; Online ISSN 2392-7054.

Web: publicatii.uvvg.ro/index.php/jls. Pages $37-47$ 
Shambel, T., (2020)

people settle by coming from other parts of the country because they may vote against secession based on their personal and property interests.

The fourth step is when the Federal Government will have transferred its powers to the council of the Nation, Nationality, or People who has voted to secede. This comes next to when the demand for secession is supported by the majority vote in the referendum. Concerning this step, the constitution does not determine the specific time range in which the transfer of power shall take place, and again it fails to mention measures to be taken if the federal government is not willing to transfer power for different reasons. It also ignores the fact that the federal government will hardly ever transfer its power by taking into account the interests of ethnic groups in the country and other people domiciled in the area which is processing secession.

The last step is when the division of assets is completed in a manner prescribed by law. With a constitutional plan to build a common economic community, the federal government agencies are the main investors of assets in different parts of the country. Even the tax base allocated to regional governments generates relatively insufficient revenues and is relatively stagnant, with low revenue buoyancy when compared to that of the federal government (Girma A. 2003). Most of the regions are fiscally dependent on the federal government and even they do not sufficiently cover their expenditure so that most of the huge assets established in the regions belong to the federal government. Therefore, fiscal dependence and division of assets is another hurdle which can potentially obstruct the secession process.

\section{Other Constitutional Constraints to Exercise Secession Right in Ethiopia}

In addition to procedural hurdles, other unintended constitutional difficulties can also be raised to deny exercising the secession right in Ethiopia. From many of the constitutional hindrances to exercise the secession right one is the 'common' ownership of land and natural resources by the nation's nationalities and people in the country. Article 40 sub-article 3 of the Ethiopian constitution provides the following concerning ownership of land and other natural resources.

The right to ownership of rural and urban land, as well as of all-natural resources, is exclusively vested in the State and in the peoples of Ethiopia. Land is a common property of the Nations, Nationalities and Peoples of Ethiopia and shall not be subject to sale or other means of exchange.

From this article one can understand that every piece of land in the Ethiopian territory is subject to the common ownership of all ethnic groups and it cannot be sold or exchanged. If every parcel of land is commonly owned by all nations, nationalities, and people, it is not at all possible to secede because other ethnic groups in the other parts of the country can claim the piece of land which is 
Shambel, T., (2020)

occupied by the ethnic group demanding secession. Even article 39 which talks about secession right and article 52 which lists the powers and functions of regional governments do not give ownership right or any other equivalent right to nations, nationalities, and people concerning the land they occupy except administering and establishing institutions in their territory (FDRE constitution 1995). Administering and establishing institutions does not guarantee ownership of the land on which institutions are established. Not only land but also the ownership of other natural resources are exclusively vested in the State and in the peoples of Ethiopia (FDRE constitution 1995). Therefore, any group, either ethnic or any other group, cannot take a resource or a piece of land without the consent of the all people of Ethiopia. Exercising secession right without land and resources is unthinkable so that this is one of the constitutional constraints that can potentially hinder secession from Ethiopia.

Another unintended constitutional restriction against secession right is the derogability of sub-articles of article 39, except sub-article 1 and 2. Under Article 93 sub-article 3 of the constitution, it is clearly stated that article 1, 18, 25 and $39 / 1 /$ and $/ 2 /$ are the only non-derogable articles which are not subject to suspension in times of a state of emergency. As discussed above, the first subarticle of article 39 enshrines unconditional secession right for nations, nationalities, and people. This right can be effective only if procedures under subarticle 4 are applied. But according to article 93, the sub-articles of article 39 except sub-article 1 and 2, are subject to suspension or they are derogable in times of a state of emergency. This means, the federal government can declare a state of emergence and suspend the secession procedures under article 39 sub-article 4, in case it believes that the secession question endangers the constitutional order in the country. If procedures under sub-article 4 of article 39 are suspended, it rightly suspends the right to secession under sub-article 1 of the same article. From this one can conclude that the non-derogability of secession right in the Ethiopian constitution is wrong because if procedures are derogable the substance is also derogable. Therefore, the federal government may obstruct the exercise of secession by nations, nationalities, and people by declaring a state of emergency, if it does not want the secession of any ethnic group from Ethiopia, provided that there is a ground to believe that the secession question caused the breakdown of systems which endangers the constitutional order.

\section{Conclusions}

Even though the inclusion of a secession right in the Ethiopian constitution is a point of legal and political debate, it is constitutionally recognized as one of the rights of nations, nationalities, and people in the country. A major justification for its inclusion in the constitution was the narrative that nations, nationalities and 
Shambel, T., (2020)

The constitutional hurdles to exercise secession right and arguments on its inclusion in the Ethiopian Constitution

people in the country were oppressed. But still, there is disagreement among politicians and scholars concerning the kind of oppression. Those who justify the inclusion of secession right argue that there were nation oppressions in which one ethnic group colonized and oppressed others; therefore, the constitutional recognition of self-determination that includes secession was perceived to be a solution.

The author of this article believes that there was no ethnic or national oppression. Rather there was class oppression in which the ruling class from different ethnic groups oppressed all the other ethnic groups so that all ethnic groups struggled to remove unjust systems. Furthermore, to claim independence, no one of the ethnic groups in Ethiopia had their own independent and internationally recognized state, and also all of them do not fulfill those exceptional conditions in which sub-state groups can exercise the external self-determination right as discussed in part two of this paper. Therefore, the solution should not have been including a secession right into the constitution but should rather have been the promotion of social justice in the country.

Despite, the disagreements concerning its inclusion in the constitution, the constitution itself has also constraints that can potentially obstruct the exercising of the right to secession. The major constraints are the constitutional procedures listed under article 39 sub-articles 4 of the constitution that must be complied with before a declaration of secession. Even though the right is given to all ethnic groups in the country unconditionally, there are five consecutive constitutional procedures listed in the above-mentioned article. As examined under part five of this paper, each of the procedures is not easy to fulfill, particularly when the systems in the country become stronger than what it looks now. Furthermore, the government can suspend the application of those procedures to deny secession; if it believes that the secession question is causing disorder which endangers the constitutional order in the country.

In addition to the procedural hurdles, the common ownership of land and other natural resources by all nations, nationalities, and people of the country is another constitutional barrier to the exercise of the secession right. According to article 40 of the constitution, the state and people own the natural resources and every piece of land within the territory of the country. Thus, without the consent of all nations, nationalities, and people, as well as the government, it is not possible to take away a piece of land or natural resource. Getting consent from every one of nations, nationalities, and people is more difficult than even overcoming the abovementioned procedural hurdles. Therefore, though granted unconditionally, exercising the right to secession in Ethiopia is not easy because of constraints the constitution itself contains. 
Shambel, T., (2020)

The constitutional hurdles to exercise secession right and arguments on its inclusion in the Ethiopian Constitution

\section{Acknowledgments}

The author thanks the anonymous reviewers and editor for their valuable contribution.

\section{Funding}

This research received no specific grant from any funding agency in the public, commercial, or not-for-profit sectors.

\section{Author Contributions}

The entire article was written by Teshale Shambel.

\section{Disclosure Statement}

The author has not any competing financial, professional, or personal interests from other parties.

\section{References}

1. Abate, N., (2004). Ethnic Federalism in Ethiopia: Challenges and Opportunities, Master thesis: University of Lund, Faculty of Law.

2. Abbink, J., (1998). New configurations of Ethiopian ethnicity: The challenge of the South. To the memory of Jacques Bureau 1947-1998. Northeast African Studies.

3. Abbink, J., (1998). "New Configurations of Ethiopian Ethnicity: The Challenge of the South," Northeast African Studies.

4. Aregawi, B., (2009). A political history of the Tigray People's Liberation Front (19751991). Revolt, ideology and mobilization in Ethiopia. Los Angeles.

5. Cassese A., (1995). Self-Determination of Peoples: A Legal Reappraisal (Cambridge University Press, Cambridge.

6. Belete, M., (2018). The Right To Self Determination Under the FDRE Constitution: Issues, Challenges And The Way Forward.

7. Clapham, C., (2002). Rewriting Ethiopian history. Annales d'Éthiopie.

8. Christophe Van der, B., (2007). Federalism and the Accommodation of Ethnic Diversity: The Case of Ethiopia.

9. Girma, A., (2003). An economic analysis of fiscal federalism in Ethiopia (2nd ed., Vol. 10, p. 127). Michigan State University.

10. Hernard, (1999). Self-determination and Cultural Diversity, in Y.Donders, K.Hernard et. al.(eds.), Law and Cultural Diversity,(SMS) Special No.25.

11. Hernard, (1999). Self-determination and Cultural Diversity, in Y.Donders, K.Hernard et.Al.(eds.), Law and Cultural Diversity,(SMS) Special No.25.

12. Johan, D., van der Vyver, (2004). The right to self-determination and its enforcement, ILSA Journal of International \& Comparative Law Vol. 10 No: 421.

13. Markakis, J., (1998). Resource Conflict in the Horn of Africa (London: SAGE Publications).

14. Merera, G., (2003). Ethiopia: Competing ethnic nationalisms and the quest for democracy, 19602000. Addis Ababa: Chamber Printing House.

46 Journal of Legal Studies Volume 26 Issue 40/2020 ISSN 2457-9017; Online ISSN 2392-7054.

Web: publicatii.uvvg.ro/index.php/jls. Pages $37-47$ 
Shambel, T., (2020)

The constitutional hurdles to exercise secession right and arguments on its inclusion in the Ethiopian Constitution 15. Merera, G., (2006). Contradictory interpretations of Ethiopian history: The need for a new consensus. In Turton, D. (Ed.), Ethnic federalism: The Ethiopian experience in comparative perspective (pp. 119-129). Oxford \& Addis Ababa: James Currey \& Addis Ababa University Press.

16. Reuter, T.K., (2016). The Right to Self-Determination of Ethnic Groups: The Canton of Jura in Switzerland.

17. Reuter, T.K. (2009). 'Dealing with Claims of Ethnic Groups in International Law', Connecticut Journal of International Law.

18. Suksi, M., 'Keeping the Lid on the Secession Kettle - A Review of Legal Interpretations Concerning Claims of Self-Determination by Minority Populations', 12:2 International. 